\title{
NILAI KEADILAN PUTUSAN HAKIM PADA PERKARA TINDAK PIDANA KORUPSI
}

\author{
H. Muslihin Rais
}

Pengurus AAI (Assosiasi Advokat Indonesia)

\begin{abstract}
The fairness of the judge's verdict on corruption cases is essentially embodied in order to prevent unfair or impartial treatment, so that justice seekers perceive as a judgment in accordance with their legal or legal beliefs, as well as avoid punishable judgments and violate the right of Perpetrator of a crime or deviate from the principle of presumption of innocence; The judge's decision on a corruption criminal case that reflects the value of justice is determined by the criteria, if the judge's decision is made in a professional manner, and supported by the moral integrity of a high judge, the judge's judgment is deemed to contain the values of justice; And Factors affecting the judge's decision, so as not to reflect the value of justice in corruption cases due to the quality of judges, the independence of judges and the intervention in examining and adjudicating cases.

To realize the value of justice in the decision of criminal case required the independence and accountability of the judges of Corruption Court in examining and prosecuting corruption criminal cases. To improve the professionalism and moral integrity of judges it is necessary to have intensive guidance and supervision of judges in examining and prosecuting cases of corruption; In order to realize a judge's judgment of fair value, it is necessary to have justice indicators in the judgment judgment assessment and to open the widest access for the public to obtain information about the judge's decision.
\end{abstract}

\section{Keywords:}

The value of justice, Verdict, Corruption

\begin{abstract}
Abstrak
Nilai keadilan putusan hakim pada perkara tindak pidana korupsi pada hakikatnya diwujudkan untuk mencegah terjadinya perlakuan yang tidak seimbang atau memihak, sehingga para pencari keadilan merasakan sebagai putusan yang sesuai dengan keyakinan hokum atau perasaan hukumnya, serta terhindar dari adanya putusan yang bertendensi penghukuman dan melanggar hak dari pelaku tindak pidana atau menyimpang dari asas praduga tak bersalah; Putusan hakim pada perkara pidana korupsi yang mencerminkan nilai
\end{abstract}


keadilan ditentukan dengan kriteria, jika putusan hakim dilakukan dengan secara professional, dan didukung dengan integritas moral hakim yang tinggi, maka putusan hakim sudah dipandang mengandung nilai-nilai keadilan; dan Faktor-faktor yang mempengaruhi putusan hakim, sehingga tidak mencerminkan nilai keadilan pada perkara tindak pidana korupsi disebabkan karena kualitas hakim, kemandirian hakim dan adanya intervensi dalam memeriksa dan mengadili perkara.

Untuk mewujudkan adanya nilai keadilan dalam putusan perkara pidana diperlukan adanya independensi dan akuntabilitas hakim Pengadilan Tipikor dalam memeriksa dan mengadili perkara tindak pidana korupsi. Untuk meningkatkan profesionalisme dan integritas moral hakim perlu dilakukan pembinaan yang intensif dan pengawasan terhadap hakim dalam memeriksa dan mengadili perkara tindak pidana korupsi; Untuk dapat terwujudnya putusan hakim yang bernilai keadilan, diperlukan adanya indikator - indikator keadilan dalam penilaian putusan hakim dan membuka seluasluasnya akses bagi masyarakat untuk mendapatkan informasi mengenai putusan hakim.

\section{Kata Kunci:}

Nilai keadilan, Putusan, Tipikor

\section{A. Pendahuluan}

$\mathrm{P}$ erkembangan masyarakat saat ini selalu diiringi dengan peningkatan tindak kejahatan khususnya tindak pidana korupsi. Masyarakat pada dasarnya merupakan suatu sistem yang terdiri dari sub-sub sistem. Sub sistem ini memiliki kepentingan yang berbeda - beda satu sama lain. Perbedaan kepentingan antara sub sistem ini dapat menimbulkan suatu benturan kepentingan antara satu dengan yang lainnya. Apabila benturan - benturan kepentingan tersebut dibiarkan maka lambat laun akanterakumulasi dalam sikap dan menimbulkan perbuatan jahat yang dikenal dengan istilah kejahatan atau kriminalitas.

Menurut Platodalam bukunya "Republiek", menyatakan kalau sumber kejahatan adalah emas dan manusia, maka makin merosot penghargaan terhadap kesusilaan. Pendapat ini menggambarkan bahwa dalam setiap negara yang banyak orang miskinnya, maka terdapat banyak penjahat-penjahat, pemerkosaan agama, dan tukang copet. ${ }^{1}$

Saat ini hampir setiap orang tidak merasa malu menyandang predikat sebagai tersangka/terdakwa dalam kasus tindak pidana korupsi sehingga hampir tidak salah kalau ada orang yang menyebutkan korupsi sudah membudaya atau dengan kata lain sesuatu hal yang biasa atau lumrah untuk dilakukan dalam zaman abad modern

\footnotetext{
${ }^{1}$.Wahyu Muljono, 2012. Pengantar Teori Kriminologi, Pustaka Yustisia, Yogyakarta.
} 
ini. Para pelaku tindak pidana korupsi tidak terlepas dari suatu perlindungan hukum. ${ }^{2}$ Yang berkaitan dengan masalah korupsi sebagai berikut:

"Masalah korupsi terkait dengan kompleksitas masalah, antara lain, masalah moral/sikap mental, masalah pola hidup, kebutuhan serta kebudayaan dan lingkungan sosial, masalah kebutuhan/tuntutan ekonomi dan kesejahteraan sosial ekonomi, masalah struktur/sistem ekonomi, sistem budaya politik, masalah mekanisme pembangunan dan lemahnya birokrasi atau prosedur administrasi (termasuk sistem pengawasan) di bidang keuangan dan pelayanan publik". ${ }^{3}$

Dalam hal ini seorang Hakim sangat erat kaitannya saat menjatuhkan ponis kepada pelaku tindak pidana korupsi akan tetapi di Indonesia hak - hak asasi manusia diakui dan hakim tidak boleh asal memutus perkara karena sudah tercantum dalam Pembukaan UUDNRI Tahun 1945, tetapi dalam diktumnya yang secara jelas tertulis hanya mengakui beberapa macam hak - hak asasi manusia saja, yaitu:

1. Persamaan kedudukan bagi semua warga negara di dalam hukum dan pemerintahan (Pasal 27 ayat 1 ).

2. Kemerdekaan berserikat dan berkumpul (Pasal 28).

3. Hak untuk mengeluarkan pikiran dengan lisan dan tulisan (Pasal 28)

4. Kemerdekaan tiap penduduk untuk memeluk agama dan kepercayaannya. ${ }^{4}$

Selain itu, di dalam Undang - Undang Nomor 48 Tahun 2009 Tentang Kekuasaan Kehakiman disebutkan tentang hak - hak asasi manusia antara lain, sebagai berikut:

1. Hakim dan hakim konstitusi wajib menggali, mengikuti, dan memahami nilainilai hukum dan rasa keadilan yang hidup dalam masyarakat (Pasal 5 ayat (1).

2. Tidak seorang pun dapat dihadapkan di depan pengadilan, kecuali undangundang menentukan lain (Pasal 6 ayat 1 ).

3. Tidak seorang pun dapat dijatuhi pidana, kecuali apabila pengadilan karena alat pembuktian yang sah menurut undang-undang, mendapat keyakinan bahwa seseorang yang dianggap dapat bertanggungjawab telah bersalah atas perbuatan yang didakwakan atas dirinya (Pasal 6 ayat 2 ).

4. Tiada seorang pun dapat dikenakan penagkapan, penahanan, penggeledahan, dan penyitaan, kecuali atas perintah tertulis dari kekuasaaan yang sah dalam hal dan menurutcara yang diatur dalam undang-undang (Pasal 7).

5. Setiap orang yang disangka, ditangkap, ditahan, dituntut, atau dihadapkan di depan pengadilanwajib dianggap tidakbersalah sebelum ada putusan pengadilan yang menyatakan kesalahannya dan telah memperoleh kekuatan

${ }^{2}$.Edi Yunara, 2012. Korupsi dan Pertanggung Jawaban Pidana Korporasi, PT.Citra Aditya Bakti,Bandung.

3. Edi Yunara, 2012. Korupsi dan Pertanggung Jawaban Pidana Korporasi, PT.Citra Aditya Bakti,Bandung, hal. 9

${ }^{4}$.Pasal 27 dan Pasal 28 UUD NRI Tahun 1945 
hukum tetap (Pasal 8).

6. Seseorang yang ditangkap, ditahan, dituntut, atau diadili tanpa alasanberdasrkan Undang-undang atau karena kekeliruan mengenai orangnya atau hukum yang diterapkannya, berhak menuntut ganti kerugian dan rehabilitasi.( Pasal 9 ayat1). ${ }^{5}$

Peradilan Negara merupakan prinsip operasionalitas kerja dari badan - badan peradilan Indonesia dalam menyelenggarakan fungsi kekuasaan kehakiman. Hal ini secara tegas diatur pada Pasal 2 ayat (1), (2) dan ayat (3) UU No. 48 Tahun 2009, sebagai berikut:

1. Peradilan dilakukan "Demi Keadilan Berdasarkan Ke Tuhanan Yang Maha Esa”.

2. Peradilan Negara menerapkan dan menegakkan Hukum dan keadilan berdasarkan Pancasila.

3. Semua peradilan di seluruh Wilayah Negara Republik Indonesia adalah peradilan Negara yang diatur dengan Undang - undang. ${ }^{6}$

Pengadilan sebagai institusi Negara yang dibentuk dalam rangka melaksanakan proses peradilan, dalam konsep Islam merupakan aspek penting yang harus dilaksanakan oleh Hakim sebagai wali Tuhan. Hal ini dengan tegas Allah SWT telah berfirman dalam QS. An-Nisa: 58:

Artinya:

Sesungguhnya Allah menyuruh kamu menyampaikan amanat kepada yang berhak menerimanya, dan menyuruh kamu apabila menetapkan hukum diantara manusia supaya kamu menetapkan dangan adil. sesungguhnya Allah memberi pengajaran yang sebaik baiknya kepadamu. Sesungguhnya Allah adalah Maha mendengar lagi maha Melihat.

Di dalam Pasal 24 Undang-Undang Dasar Negara Republik Indonesia Tahun 1945 (UUD NRI Tahun 1945), juga dicantumkan secara jelas tentang kekuasaan kehakiman sebagai kekuasaan yang merdeka untuk menyelenggarakan peradilan guna menegakkan hukum, dan keadlian yang dilakukan oleh Mahkamah Agung dan badan peradilan yang berada dibawahnya dalam lingkungan peradilan umum, lingkungan peradilan agama, lingkungan peradilan militer, lingkungan peradilan tata usaha Negara dan oleh sebuah Mahkamah Konstitusi.

Penjabaran mengenai kekuasaan kehakiman dalam bentuk hukum positif yang ditemukan dalam ketentuan Undang-Undang Nomor14 Tahun 1970 sebagaimana diubah dengan Undang-Undang Nomor 35 Tahun 1999 tentang KetentuanKetentuan Pokok Kekuasaan Kehakiman, dan terakhir Undang Undang Nomor 48 Tahun 2009 Tentang Kekuasaan Kehakiman, khususnya dalam Pasal 1 ditegaskan bahwa "kekuasaan kehakiman adalah kekuasaan Negara yang merdeka untuk menyelenggarakan peradilan guna menegakkan hukum dan keadilan berdasarkan Pancasila, demi terselenggaranya Negara Hukum Republik Indonesia". Bahkan

\footnotetext{
5. Undang-Undang Nomor 48 Tahun 2009 Tentang Kekuasaan Kehakiman

${ }^{6}$.Undang-Undang Nomor 48 Tahun 2009 Tentang Kekuasaan Kehakiman
} 
dalam Pasal 4 ayat (1) lebih jelas dikemukakan bahwa "peradilan dilakukan demi keadilan berdasarkan Ketuhanan Yang Maha Esa". Sedangkan Pasal 4 ayat (3) secara tegas melarang pihak-pihak lain di luar kekuasaan kehakiman untuk turut campur dalam urusan peradilan.

Dalam kajian diagnostik oleh lembaga kajian dan advokasi untuk independesi peradilan di Indonesia, khususnya menyangkut reformasi kekuasaan kehakiman di Indonesia ditegaskan, bahwa yang harus menjadi inti dari reformasi di bidang kekuasaan kehakiman adalah:

1. Menjadikan kekuassan kehakiman sebagai sebuah institusi yang indenpenden;

2. Mengembalikan fungsi yang hakiki dari kekuasaan kehakiman untuk mewujudkan keadilan dan kepastian hukum;

3. Menjalankan fungsi chek and balances bagi institusi kenegaraan lainnya;

4. Mendorong dan memfasilitasi serta menegakkan prinsip-prinsip Negara hukum yang demokratis guna mewujudkan kedaulatan rakyat;

5. Melindungi martabat kemanusiaan dalam bentuk yang paling konkrit. Juga disimpulkan bahwa kondisi kekuasaan kehakiman di Indonesia tampak masih memperhatinkan, dan secara umum dapat dikatakan bahwa kekuasaan kehakiman di Indonesia tidak mandiri, tidak bersih dan tidak professional.Penyebab kondisi ini ditinjau dari 3 aspek, yaitu aspek katata negaraan, kelembagaan pengadilan dan aspek penegak hukum. ${ }^{7}$

Hakim sebagai penegak keadilan dan hukum, harus profesional dan memiliki integritas moral yang tinggi serta kemandirian dalam memeriksa dan memutus perkara, karena dengan hal itulah diharapkan tidak terjadi kekeliruan dan kesalahan dalam menegakkan keadilan dan hukum, hal mana sejalan dengan hadits Nabi Muhammad Saw, yang diriwayatkan oleh Abu Daud.Bersabda bahwa hakim ada tiga macam, satu di surga dan dua di neraka, yang disurga adalah hakim yang memiliki pengetahuan tentang kebenaran dan memutuskan dengannya, sedangkan yang mengetahui kebenaran dan menyimpang darinya dalam menerapkan hukum dia di neraka, dan yang menetapkan hukum yang didasari oleh kebodohan juga di neraka.

Mewujudkan nilai keadilan dan kepastian hukum dalam setiap putusan hakim tidaklah mudah, sebab dalam sistem Hukum di Indonesia tidak dikenal adanya mekanisme "dissenting opinion", apalagi melakukan akses secara terbuka terhadap hasil proses yang menjadi bahan putusan hakim (close system), terlebih lagi dalam kaitan profesionalisme hakim dalam penguasaan hukum (rechtsvinding), serta integritas moral yang dimiliki dengan komitmen mengutamakan putusan yang adil.

Ketua Mahkamah Agung Republik Indonesia Bagir Manan mengemukakan bahwa pembangunan hukum nasional dihadapkan pada beberapa masalah, yakni: pertama, masalah sistem putusan hakim yang tidak mengikat (no-binding) artinya

\footnotetext{
7. lembaga kajian dan advokasi untuk independesi peradilan di Indonesia (1999: XII-75).
} 
putusan hakim yang lebih baru, tidak terikat pada yang lalu bahkan putusan Mahkamah Agung-pun secara legal tidak mengikat terhadap yang lain; kedua, adalah bagaimana mendudukkan yurisprudensi menjadi subsistem yang baik dalam tata hukum Indonesia. Akibat sistem yurisprudensi yang tidak baik, dimana putusan pengadilan berbeda-beda atas perkara mengenai hal yang sama, obyek yang sama, dengan majelis yang berbeda mengakibatkan terjadi inkonsistensi besar-besaran; ketiga, sistem pendidikan hukum di Perguruan Tinggi yang sangat jarang menggunakan yurisprudensi sebagai bahan pendidikan akibatnya kurang didapati komentar, ataupun notasi atas putusan hakim; keempat, adalah keterbatasan fasilitas untuk mengakses putusan Mahkamah Agung; kelima, adalah publikasi yurisprudensi.

Selanjutnya upaya untuk meningkatkan kualitas putusan pengadilan, Mahkamah Agung Republik Indonesia dalam Intruksinya No. KMA/015/inst/VI/1998 tanggal 1 Juni 1998, menginstruksikan agar para hakim menetapkan profesionalisme dalam mewujudkan peradilan yang berkualitas dengan putusan hakim yang eksekutabel berisikan ethos (integritas), pathos (pertimbangan yuridis yang pertama dan utama), filosofis (berintikan rasa keadilan dan kebenaran), sosiologis (sesuai dengan tata nilai budaya yang berlaku dimasyarakat), logos (diterima dengan akal sehat) demi terciptanya kemandirian para penyelenggara kekuasaan kehakiman.

Putusan hakim yang baik bukan hanya dapat membentuk "iusconstitutum", tetapi juga "ius constituendum" melalui mekanisme yurisprudensi sebagai salah satu sumber hukum, namun masalahnya adalah tidak terdapat tolak ukur atau kriteria yang jelas, tentang apa yang dimaksudkan dengan putusan hakim itu dianggap baik, oleh Majelis Hakim tetapi bagi masyarakat pencari keadilan hal itu justru sebaliknya, yakni putusan tersebut tidak mencerminkan nilai keadilan dan tidak dapat diterima oleh masyarakat.

Dalam berbagai penanganan kasus tindak pidana korupsi, seringkali mencuat menjadi bahan perbincangan publik, karena putusan pengadilan dianggap mengabaikan nilai-nilai keadilan yang semestinya dirasakan oleh masyarakat dan pencari keadilan.Salah satu penyebabnya, adalah adanya korupsi peradilan (judicial corruption) yang lebih popular disebut dengan mafia peradilan, yaitu adanya konsfirasi dan penyalahgunaan wewenang di antara aparat keadilan untuk mempermainkan hukum demi keuntungan pribadi.Banyaknya intervensi dan tekanan pihak luar terhadap hakim, terkadang membuat kinerja hakim tidak lagi optimal, atau bahkan memilih sikap oppurtunis.Tidak semua hakim dapat mengatakan yang benar adalah benar, dan yang salah adalah salah. Belum lagi munculnya makelar kasus yang menghalalkan segala cara, seperti jual beli perkara, semakin menambah coreng moreng dunia peradilan ${ }^{8}$.

Sejak Undang-undang Nomor 31 Tahun 1999 diundangkan, sehingga timbul

${ }^{8}$ Danang Widoyoko, et.al, Menyingkap Tabir Mafia Peradilan, ICW, Jakarta, 2002, hal. 24 
suatu anggapan adanya kekosongan hukum untuk memproses tindak pidana korupsi yang terjadi sebelum berlakunya Undang-Undang Nomor 31 Tahun 1999. ${ }^{9}$

\section{B. Analisis Dan Pembahasan}

\section{Hakikat Nilai Keadilan Dalam Putusan Hakim Pada Perkara Tindak Pidana Korupsi}

\section{a. Putusan sebagai Instrumen peradilan}

Putusan pada hakikatnya memuat segala kegiatan atau proses peradilan dalam rangka penyelesaian perkara yang sejak awal telah membebani pihak-pihak. Dari rangkaian proses peradilan tidak satupun di luar putusan peradilan yang dapat menentukan hak suatu pihak dan beban kewajiban pada pihak lain, sah tidaknya suatu tindakan menurut hukum dan meletakkan kewajiban untuk dilaksanakan oleh pihak dalam perkara. Di antara proses peradilan hanya putusan yang menimbulkan konsekuensi kepada para pihak.

MenurutAndi Hamzah bahwa putusan adalah hasil atau kesimpulan dari suatu perkara yang telah dipertimbangkan dengan masak-masak yang dapat berbentuk putusan tertulis maupun lisan. ${ }^{10}$ Sedangkan Sudikno Mertokusumo memandang bahwa putusan hakim adalah suatu pernyataan yang oleh hakim, sebagai pejabat negara yang diberi wewenang untuk itu, diucapkan di persidangan dan bertujuan untuk mengakhiri atau menyeleseiakan suatu perkara atau sengketa antara para pihak. ${ }^{11}$ Kendatipun demikian, Sudikno Mertokusumo berpendapat bahwa bukan hanya yang diucapkan saja yang disebut putusan, melainkan juga pernyataan yang dituangkan dalam bentuk tertulis dan kemudian diucapkan oleh Hakim di persidangan. Sebuah konsep putusan (tertulis) tidak mempunyai kekuatan sebagai putusan sebelum diucapkan di persidangan oleh hakim. ${ }^{12}$

Dalam KUHAP pengertian putusan secara umum tidak dijumpai, tetapi putusan menurut KUHAP adalah putusan pengadilan. Dalam Pasal 1 angka 11 KUHAP, ditegaskan bahwa putusan pengadilan adalah pernyataan hakim yang diucapkan dalam siding terbuka, yang dapat berupa pemidanaan atau bebas atau lepas dari segala tuntutan hukum dalam hal serta menurut cara yang diatur dalam undang-undang ini.

Suatu perkara pidana diajukan kepada pengadilan untuk mendapatkan penyelesaian dan menetapkan hak atau hukumnya, serta pelaksanaannya secara paksa. Pemeriksaan perkara memang diakhiri dengan putusan, akan tetapi dengan lahirnya putusan saja belumlah selesai persoalannya. Sebuah keputusan yang ditetapkan pengadilan harus dapat dilaksanakan atau dijalankan.Karena itu,

${ }^{9}$.Undang-undang Nomor 31 Tahun 1999 tentang Pemberantasan Tindak Pidana Korupsi (Lembaran Negara Republik Indonesia Tahun 1999 Nomor 140, Tambahan Lembaran Negara Republik Indonesia Nomor 3874).

\footnotetext{
${ }^{10}$ Andi Hamzah, Hukum Acara Perdata, (Yogyakarta: Liberty, 1986), hlm. 485.

${ }^{11}$ Sudikno Mertokusumo, Hukum Acara... op.cit., hlm. 206.

${ }^{12}$ Ibid, hlm. 175 .
} 
putusan hakim mempunyai kekuatan eksekutorial, kekuatan untuk dilaksanakan apa yang ditetapkan dalam putusan itu secara paksa oleh alat-alat negara. Pelaksanaan putusan hakim atau eksekusi pada hakikatnya adalah realisasi dari kewajiban pihak yang bersangkutan untuk memenuhi prestasi yang tercantum dalam putusan tersebut. ${ }^{13}$

Suatu putusan memberikan arti berakhirnya suatu proses penyelesaian perkara setelah melalui beberapa tahapan sebagai berikut:

a. Pembacaan surat dakwaan;

b. Pembacaan keberatan (eksepsi) terdakwa atau penasihat hukum terhadap surat dakwaan dan pembacaan pendapat penuntut umum;

c. Pembacaan putusan sela (tuss end vonnis) oleh hakim;

d. Pemeriksaan alat-alat bukti yang terdiri atas:

- Keterangan saksi;

- Keterangan ahli;

- Surat;

- Petunjuk;

- Keterangan terdakwa.

e. Pembacaan tuntutan pidana (requisatoir) oleh penuntut umum;

f. Pembacaan pembelaan (pledooi) oleh terdakwa dan atau penasihat hukum;

g. Pembacaan jawaban penuntut umum terhadap pembelaan terdakwa dan atau penasihat hukum;

h. Pembacaan jawaban terdakwa dan atau penasihat hukum terhadap jawaban penuntut umum kalau ada;

i. Pembacaan putusan hakim.

Sebelum diundangkan Kitab Undang Undang Hukum Acara Pidana (KUHAP) yang dikenal dengan Undang Undang No. 8 Tahun 1981(LN RI Tahun 1981 No. 76), system peradilan pidana di Indonesia dilandaskan pada Het Herziene Inlandsch Reglement atau HIR (Stbl. 1941 No. 44), yang menurut Romli Atmasasmita menganut sistem campuran atau the mixed type, bukan menganut system inkuisitur sebagaimana sering diungkapkan oleh sebagian besar ahli hukum di Indonesia.Kekeliruan pandangan telah terjadi terhadap esensi sistem inkuisitur.Sebenarnya prosedur inkuisitur dalam perkara pidana melarang dilakukannya penyiksaan untuk memperoleh pengakuan (confession) $)^{14}$. Sistem inkuisitur ini, muncul dan berkembang justru setelah cara penyiksaan sejak lama dilarang dan dipandang sebagai melanggar hukum ${ }^{15}$.

Apabila ditelaah proses penyelesaian perkara pidana berdasarkan KUHAP, dapat dibagi dalam tiga tahap, yaitu tahap sebelum sidang pengadilan (pra

\footnotetext{
${ }^{13}$ Ibid., h. 211

${ }^{14}$ Romli, Op.cit, hlm.29

15 Damaska, Op.cit, hlm. 558
} 
ajudikasi); tahap sidang pengadilan (ajudikasi); dan tahap setelah pengadilan (purna ajudikasi) ${ }^{16}$.

Suatu putusan adalah pada dasarnya memberikan suatu kepastian hukum dan keadilan terhadap terdakwa. Proses hukum dalam pentahapan sistem KUHAP tersebut, dapat diuraikan sebagai berikut:

1. Tahap pra ajudikasi, meliputi:

a. penyelidikan dan penyidikan serta pengumpulan alat-alat bukti dan barang bukti;

b. pra penuntutan dan penuntutan supaya perkara itu di sidangkan.

2. Tahap ajudikasi, meliputi pemeriksaan di depan sidang pengadilan:

a. verifikasi tentang identitas terdakwa;

b. pembacaan surat dakwaan oleh penuntut umum

c. pengajuan (jika ada) keberatan (eksepsi) dari terdakwa/penasihathukum;

d. pemeriksaan saksi-saksi dan alat bukti lainnya;

e. pemeriksaan terdakwa;

f. penelitian dan konfirmasi terhadap barang bukti;

g. tuntutan pidana (requisitoir);

h. pembelaan (pledoi) oleh terdakwa/penasihat hukum; dilanjutkan dengan reflik dari penuntut umum dan duplik dari terdakwa/penasihat hukum;

i. putusan hakim.

3. Tahap purna ajudikasi, meliputi:

a. pemberitahuan tentang hak para pihak (terdakwa dan penuntut umum) untuk menerima atau menolak putusan;

b. eksekusi dan pengawasan dan pengamatan.

Selanjutnya dalam Sistem Peradilan Pidana Indonesia, yang berlandaskan KUHAP memilik 10 (sepuluh) asas, yaitu:

1. Perlakuan yang sama di muka hukum, tanpa diskriminasi apa pun;

2. Praduga tak bersalah;

3. Hak untuk memperoleh kompensasi (ganti rugi) dan rehabilitasi;

4. Hak untuk memperoleh bantuan hukum;

5. Hak kehadiran terdakwa di muka pengadilan;

6. Peradilan yang bebas dan dilakukan dengan cepat dan sederhana;

7. Peradilan yang terbuka untuk umum;

8. Pelaksanaan atas hak-hak warga Negara (penangkapan, penahanan, penggeledahan dan penyitaan) harus didasarkan pada undang-undang dan dilakukan dengan surat perintah (tertulis);

9. Hak seorang tersangka untuk diberitahu tentang persangkaan dan pendakwaan terhadapnya; dan

\footnotetext{
${ }^{16}$ Mardjono, Op.cit, hlm.12
} 
10. Kewajiban pengadilan untuk mengendalikan pelaksanaan putusannya ${ }^{17}$.

Konsekuensi logis dianutnya due process of lawatau proses hokum yang adil atau layak dalam KUHAP, menurut Mardjono bahwa sistem peradilan pidana Indonesia selain harus melaksanakan penerapan hokum acara pidana sesuai dengan sepuluh asas, juga harus didukung oleh sikap batin (penegak hukum) yang menghormati hak-hak warga masyarakat. Suatu proses hukum yang adil pada intinya, adalah hak seorang tersangka dan terdakwa untuk didengar pandangannya tentang bagaimana peristiwa kejahatan itu terjadi, dalam pemeriksaan terhadapnya dia berhak didampingi oleh penasihat hukum; diapun berhak mengajukan pembelaan, dan penuntut umum harus membuktikan kesalahannya di muka suatu pengadilan yang bebas dan dengan hakim yang tidak berpihak. ${ }^{18}$

Oliver Stolpe dalam Andi Samsan Nganro mengemukakan bahwa Perlindungan terhadap hak-hak asasi dan keamanan manusia yang efektif masingmasing memerlukan adanya lembaga peradilan yang berfungsi dengan baik dan berintegritas, yaitu yang mampu menafsirkan dan menegakkan hukum secara adil, efisien dan dapat diandalkan. Persidangan yang adil merupakan salah satu hak asasi manusia yang paling mendasar, itu hanya dapat dicapai melalui pengadilan yang tidak memihak dan prosedur yang sama bagi para pihak ${ }^{19}$.

Di dalam Pasal 28D ayat (1) UUD NRI Tahun 1945 menegaskan bahwa setiap berhak atas pengakuan, jaminan, perlindungan dan kepastian hukum yang adil. Pada irah-irah tiap putusan hakim pun selalu dicantumkan "Demi Keadilan Berdasarkan Ketuhanan Yang Maha Esa", dan bukan "Demi Kepastian Hukum Berdasarkan Undang-undang". Kenyataan ini, mengandung makna bahwa hakim menjatuhkan putusan atas perkara yang ditangani, bukan hanya menerapkan dan menegakkan hukum, tetapi hakim juga menegakkan dan merumuskan keadilan. Dengan demikian, tampak bagi hakim bahwa menegakkan hukumtidak selalu sama dengan menegakkan keadilan.

Dalam konteks ini, kualitas putusan hakim ditentukan oleh sejumlah faktor antara lain, yaitu: Pertama, ideologi hakim. Sebuah keputusan direproduksi oleh hakim tidak mungkin tanpa ideologi individual yang tertanam dikepala sang hakim itu. Untuk itu, ideologi akan menjadi warna putusan hakim dalam menjatuhkan putusan; kedua, tingkat pendidikan hakim, menentukan bagaimana kualitas nalar hakim dalam menafsirkan norma hukum.

Rudolph von Jhering ${ }^{20}$ sejak awal telah mengajarkan bahwa seorang hakim bukanlah corong undang-undang atau hukum positif pada umumnya.Hakim adalah corong kepatutan, keadilan, kepentingan umum dan ketertiban umum.Apabila

\footnotetext{
${ }^{17}$ Ibid, hlm. 11-12

${ }^{18}$ Ibid, hlm. 6

19 A. Samsan Nganro, Independensi dan Akuntabilitas Hakim Pengadilan Tipikor Dlam Pemberantasan Tindak Pidana Korupsi Di Indonesia, Ringkasan Disertasi, Unpad, Bandung 2011, hlm. 45

${ }^{20}$ Muchsin, Kekuasaan Kehakiman Yang Merdeka \& Kebijakan Asasi, STIH IBLAM, Depok, 2004, $\operatorname{hlm} .3$
} 
penerapan hukum bertentangan dengan kepatutan, keadilan, kepentingan umum, atau ketertiban umum.Namun demikian, sepanjang ketentuan undang-undang sudah jelas dan tegas, maka ketentuan undang-undangitu yang harus diterapkan, kecuali apabila aturan hukum tidak jelas atau tidak ada, maka hakim wajib mencari dan menggali serta menerapkan nilai-nilai hukum dan rasa keadilan yang hidup di dalam masyarakat.Jikapun hal tersebut, tidak ada baru dilakukan penemuan hukum atau penciptaan hukum oleh hakim.Makna aturan hukum tidak ada, dalam hal ini dapat juga diartikan bahwa aturan hukumnya tidak sesuai atau bertentangan dengan keadilan dan kepatutan dalam masyarakat.

\section{b. Nilai Keadilan Dalam Putusan Hakim Pidana}

Dalam konteks hukum acara pidana sebagaimana diatur pada Pasal 1 Undang Undang Nomor 8 Tahun 1981 tentang Kitab Undang Undang Hukum Acara Pidana (KUHAP), ditentukan bahwa Hakim adalah pejabat peradilan Negara yang diberi wewenang oleh undang-undang untuk mengadili. Sementara itu, pengadilan (rechtsbank, court), secara sederhana menunjuk pada wadah, badan, lembaga atau instansi. Sedangkan peradilan (rechtspraak, judiciary) menunjuk pada fungsi, proses, atau cara memberikan keadilan, serta yang dilakukan pengadilan. Karena itu, pengertian pengadilan mencakup pengertian peradilan. ${ }^{21}$

Pada dasarnya peradilan selalu berkaitan dengan pengadilan, dan pengadilan itu sendiri bukanlah semata-mata badan, tetapi terkait juga dengan pengertian yang abstrak, yaitu memberikan keadilan. Jadi pengertian pengadilan sudah tercakup di dalamnya peradilan yang mempunyai fungsi untuk memberikan keadilan.

Suatu putusan hakim yang merupakan kesimpulan dari seluruh peristiwa dan fakta yang diperoleh hakim dalam pemeriksaan perkara, dinilai dengan berdasar pada norma hukum yang relevan dengan fakta tersebut. Selanjutnya dihubungkan dengan nilai-nilai keadilan, maka putusan hakim akan bernuansa dan memberikan nilai hukum dan keadilan, serta sekaligus memberikan kepastian dalam penyelesaian suatu kasus, terutama pada perkara tindak pidana korupsi. Kepastian hukum menekankan, agar hukum ditegakkan sebagaimana seharusnya, meskipun langit ini runtuh hukum harus ditegakkan (fiat justitia et pereat mundus). Sementara itu, nilai sosialogis menekankan pada kemanfaatan bagi masyarakat.

Dalam menyelesaikan perkara, hakim tidak bekerja demi hukum atau demi undang-undang, melainkan "Demi Keadilan Berdasarkan Ketuhanan Yang Maha Esa". Dalam Pasal 2 ayat (1) UU No. 48 Tahun 2009 tentang Kekuasaan Kehakiman, menegaskan bahwa Peradilan dilakukan "Demi Keadilan Berdasarkan Ketuhanan Yang Maha Esa", sedangkan dalam Penjelasan Pasal 2 ayat (1) UU No. 48 Tahun 2009 tentang Kekuasaan Kehakiman, menyatakan bahwa Peradilan dilakukan Demi Keadilan Berdasarkan Ketuhanan Yang Maha Esa adalah sesuai dengan Pasa 29 Undang Undang Dasar Negara Republik Indonesia Tahun 1945 yang menentukan

\footnotetext{
${ }^{21}$ Anton. M. Moeliono, Kamus Besar Bahasa Indonesia, Balai Pustaka, Jakarta, 1990, hlm. 6-7
} 
bahwa Negara berdasarkan atas Ketuhanan Yang Maha Esa dan Negara menjamin kemerdekaan tiap-tiap penduduk untuk memeluk agamanya masing-masing dan untuk beribadat menurut agamanya dan kepercayaannya itu.

Irah-irah putusan hakim tersebut, jika hanya dimaknai sebagai sekedar simbol putusan saja dalam memenuhi standar formal sahnya putusan, maka jangan pernah berharap akan lahir putusan hakim yang mengandung nilai-nilai keadilan, dan pada akhirnya jangan mengharapkan bahwa putusan hakim dapat dipertanggungjawabkan pada Tuhan, masyarakat dan untuk diri hakim itu sendiri. Karena itu, harus betul-betul dihayati bahwa irah-irah tersebut, tidak hanya sebagai simbol, tetapi harus dipandang sebagai sumpah dan komitmen hakim bahwa seluruh proses pemeriksaan mulai dari awal sampai lahirnya putusan, senantiasa dijiwai oleh irah-irah tersebut.

Frasa Berdasarkan Ketuhanan Yang Maha Esa, menjadi simbol bahwa hakim dalam menegakkan hukum dan keadilan, bertugas mewakili Tuhan Yang Maha Esa. Selain itu, frasa tersebut dapat diartikan sebagai jaminan bahwa hakim dalam menyelesaikan perkara akan bekerja secara jujur, objektif dan adil, karena ia mengatas namakan Tuhan dalam membuat putusannya. Jika tidak demikian, maka hakim yang tidak berlaku jujur, objektif dan adil, kelak akan mempertanggungjawabkannya dihadapan Tuhan Yang Maha Esa.

Tujuan dari suatu proses peradilan, adalah mewujudkan keadilan, maka hakim harus memahami makna keadilan, baik keadilan prosedural maupun keadilan substantif, serta harus memahami esensi, mekanisme dan teknis menegakkan dan menemukan hukum.

Putusan pengadilan, adalah statemen hakim yang diucapkan dalam sidang terbuka untuk umum, dalam rangka menyelesaikan atau mengakhiri suatu perkara/ kasus. Putusan dijatuhkan setelah pemeriksaan perkara selesai, dan oleh pihak-pihak yang berperkara sudah tidak ada lagi yang perlu dikemukakan. Putusan pengadilan merupakan hal yang sangat didambakan, karena dengan adanya putusan pengadilan akan memberikan kepastian hukum bagi pihak yang berperkara, atau terdakwa yang didakwa telah melakukan perbuatan tindak pidana korupsi.

Untuk memberikan putusan pengadilan yang benar-benar menciptakan adanya kepastian hukum dan mencerminkan keadilan, maka hakim yang melaksanakan peradilan, maka pada hakikatnya harus memahami dan mengetahui duduk perkara yang sebenarnya, dan peraturan hukum yang berkenaan dengan perkara tersebut untuk diterapkan, baik mengenai ketentuan hukum yang ada dalam peraturan perundang-undangan, maupun yang tidak tertulis dalam hukum adat.

Namun dalam kenyataannya, tidak selamanya hakim memiliki kesadaran untuk secara sungguh-sungguh menegakkan hukum dan keadilan.Karena itu, tidak jarang terdapat putusan hakim baik perdata maupun pidana, dipandang tidak mencerminkan nilai-nilai keadilan.Terbukti dengan banyaknya jumlah putusan hakim yang dibatalkan oleh Pengadilan Tinggi atau Mahkamah Agung.Bahkan 
terdapat putusan kasasi Mahkamah Agung, justru dibatalkan oleh Mahkamah Agung dalam tingkat penunjauan kembali, dengan alasan salah dalam menerapkan hukum. Kendatipun hakim yang mengadili dalam tingkat kasasi maupun yang mengadili dalam perkara peninjauan kembali, adalah sama-sama diperiksa Hakim Agung.Memang pada nyata, sebagian hakim integritasnya masih dapat dipertanyakan. Hal ini, tampak dari adanya beberapa kasus, seperti adanya perubahan amar putusan yang sudah dimusyawarahkan oleh majelis hakim, ataupun isu suap atau perbuatan tercela lainnya yang menyertai dikeluarkannya putusan hakim.

Salah satu kesulitan, adalah tidak adanya indikator konkrit untuk menentukan secara pasti, bagaimana wujud putusan hakim yang memenuhi rasa keadilan. Namun demikian, kategori yang dapat dijadikan standar untuk melihat suatu putusan memenuhi rasa keadilan atau tidak, adalah hanya dapat ditemukan dalam pertimbangan hukum yang digunakan hakim. Sebagaimana diketahui, pertimbangan hukum adalah merupakan dasar argumentasi hakim dalam memutuskan suatu perkara. Jika argumentasi hukum tersebut, tidak logis, tidak benar, dan tidak sepantasnya (proper), maka orang kemudian dapat menilai bahwa putusan itu tidak benar dan tidak adil. ${ }^{22}$

Sebagai salah satu pilar perwujudan kekuasaan kehakiman yang mandiri, bebas dan merdeka untuk menyelenggarakan peradilan guna menegakkan hukum dan keadilan, maka tidak ada jalan lain yang diperlukan, yaitu adanya keterbukaan dan tanggung jawab hakim dalam melahirkan putusan yang mencerminkan nilai keadilan dan kepastian. Bahkan putusan hakim yang mencerminkan nilai keadilan, merupakan suatu keharusan untuk mewujudkan ada ya peradilan jujur, fair, dan tidak memihak (diskriminatif). Adanya pembenaran bahwa putusan hakim, adalah benteng terakhir dari keadilan dalam banyak hal membuat putusan hakim itu seakan-akan, adalah wilayah tak terjamah oleh hukum itu sendiri (the judging can do no wrong).

Tuntutan kemerdekaan hakim dalam memutus perkara telah menjadi tuntutan universal, sebagaimana dalamPasal 10 Deklarasi Universal Hak Asasi Manusia (DUHAM), menegaskan bahwa:

Everyone is entitled in full equality to a fair and public hearing by an independent and impartial tribunal in the determination of his rights and obligation of any criminal charge agains him. (setiap orang berhak dalam persamaan sepenuhnya didengarkan suaranya di muka umum dan secara adil oleh pengadilan yang merdeka dan tidak memihak, dalam hal menetapkan hak-hak dan kewajiban-kewajibannya dan dalam setiap tuntutan pidana yang ditujukan kepadanya).

Independensi hakim tidak sekedar berarti imparsialitas hakim dari pengaruh eksekutif dan legislatif, bahkan dari internal lembaga yudikatif itu sendiri. Independensi

\footnotetext{
${ }^{22} \mathrm{http} / / /$ informasiana.com/pengertian-keadilan-hakikatdan macam-macam keadilan/\#
} 
tidak sekedar bermakna "merdeka, bebas, imparsialis atau tidak memihak "dengan individu, kelompok atau organisasi kepentingan apapun, atau tidak tergantung atau dipengaruhi oleh kekuatan apapun. Independensi bermakna pula sebagai kekuatan (power), paradigma, etika, spirit untuk menjamin bahwa hakim akan menegakkan hukum demi kepastian dan keadilan.

Kecenderungan adanya putusan hakim yang tidak tersentuh oleh hukum itu sendiri, pada akhirnya berakibat bahwa putusan hakim tidak lagi dapat dinilai, atau diuji oleh masyarakat pencari keadilan, selain dengan melakukan upaya hukum yang tersedia. Konsekuensi yang ditimbulkan dengan adanya putusan hakim yang tidak mengandung nilai keadilan, pada akhirnya turut mempengaruhi citra lembaga peradilan sebagai institusi yang menegakkan hukum dan keadilan dalam masyarakat.

Dalam konteks ini, menurut Paulus Hadi Suprapto ${ }^{23}$ dari hasil penelitian yang dilakukan menunjukkan bahwa putusan majelis hakim tidak mencerminkan nilai keadilan dan kemanfaatan. Hal ini, disebabkan karena kekurangpahaman majelis hakim terhadap hukum pidana materil, yang diikuti dengan rendahnya kelengkapan unsur pembuktian tindak pidana dengan kesalahan serta rendahnya penggunaan penalaran hukum logis (runtut dan sistematik), atau yang lebih mengutamakan cara berpikir silogisme berdampak pada kualitas putusan yang kurang mencerminkan nilai keadilan dan kemanfaatan bagi masyarakat. Demikian pula, pertimbangan faktor non yuridis kurang mendapat perhatian, sedangkan falsafah pemidanaannya lebih cenderung pada retributif. Sangat jarang putusan hakim pada era sekarang ini, menggunakan falsafah pemidanaan yang bersifat penjeraan (deterrence).

Jika diperhatikan dari kalangan hakim dijumpai persepsi bahwa makna dasar peradilan ini ialah putusan hakim merupakan pertanggungjawaban kepada Tuhan Yang Maha Esa.Pendapat ini, pada dasarnya sama dengan Penjelasan Umum UU PKK, bahkan dapat dikatakan pemahaman hakim yang menjadikan kalimat tersebut sebagai simbol dalam memenuhi standarformal putusan sebagai landasari eksekutorial dan formal sahnya putusan, dan rupanya kurang dipahami makna dasar kalimat tersebut, sebagai komitmen atau sumpah bagi hakim bahwa seluruh proses pemeriksaan dijiwai oleh kalimat termaksud. Kalimat ini juga tidak boleh dimaknai sebatas memenuhi standar formal putusan sebagai landasan eksekutorial.Walaupun demikian, sebagian dari kalangan hakim justru memahami dan mengaplikasikan komitmen atau sumpah hakim tersebut, yaitu mengadili dengan jujur, netral dan roh keadilan menghiasi jiwanya pada saat mengadili perkara.Pemahaman seperti ini cukup mendasar dan merupakan wujud kehendak berbuat adil. ${ }^{24}$

${ }^{23}$ Paulus Hadi Suprapto, et. al, Menemukan Substansi Dalam Keadilan Prosedural, Komisi Yudisial, Jakarta, 2009, Hlm. 62-63.

${ }^{24}$ Sukarno Aburaera, Nilai Keadilan Putusan Hakim Pada Perkara Perdata, Disertasi, PPs Universitas Hassnuddin, Makassar, 2004, hlm. 120 
Selanjutnya dari kalangan pengacara mempunyai pandangan bahwa dengan dasar peradilan ini, para hakimyang memeriksa perkara harus betul-betul bersikap obyektif, tidak memihak dan memperlakukan sama para pihak, serta dalam menjatuhkan putusan hakim harus menegakkan keadilan sesuai dengan prinsipprinsip atau ajaran Tuhan ${ }^{25}$.

Menurut Sukarno ${ }^{26}$ bahwa Hakim dalam tingkah laku dan tutur kata pada proses pemeriksaan perkara harus menunjukkan diri sebagai orang bijak, dan memiliki sifat-sifat Tuhan yang memperlakukan semua orang secara sama, menempatkan para pihak pada kedudukan sama, dan tidak pernah memperlakukan para pihak dengan berat sebelah.Jiwa dari "Demi Keadilan" harus terwujud dalam mempertimbangkan kejadian atau peristiwa dengan menempatkan fakta yang benar sebagai sesuatu yang benar dan bukan sebaliknya.Demikian juga, pada saat fakta yang benar dikualifikasi kedalam aturan hukum haruslah dengan benar, dan aturan hukum yang ditetapkan haruslah aturan hukum yang adil.Penerapan keadilan harus dicari setelah memahami dan mempelajari perkara yang diperiksa, kondisi serta aturan hukum yang menjadi dasar perkara tersebut.Kesalahan hakim dalam menetapkan hukum mungkin masih bisa dimaafkan selama hatinya tidak menyimpang dari kehendak berbuat adil, namun kesalahan yang telah diketahui, tetapi masih tetap dilakukan adalah merupakan perbuatan zalim.

Jika hakim dalam memeriksa dan memutus suatu perkara tidak menjumpai aturan hukum tertulis, maka ia wajib menggali hukum yang hidup dan memutus berdasarkan hukum sebagai seorang yang bijaksana dan bertanggung jawab kepada Tuhan Yang Maha Esa.Jika dalam proses pemeriksaan, ternyata hakim mendapati hukum tertulis yang bertentangan dengan rasa keadilan masyarakat yang Berketuhanan Yang Maha Esa, maka hakim haruslah berusaha dan berani melenturkan aturan-aturan hukum tertulis atau mengesampingkan demi memenuhi rasa keadilan yang berdasarkan Ketuhanan Yang Maha Esa.Kehendak untuk berbuat adil berdasarkan Ketuhanan Yang Maha Esa bukanlah sesuatu yang sulit, oleh karena hal ini semata-mata tergantung pada manusianya. Manusia-manusia yang beriman dan meyakini bahwa ada hari pembalasan terhadap yang telah diperbuatnya di dunia, akan selalu berusaha berbuat, bertingkah laku yang baik, jujur dan netral sebagai salah satu wujud aplikasi dari keadilan yang berdasarkan Ketuhanan Yang Maha Esa ${ }^{27}$.

Adanya kebebasan dan kemandirian dari hakim dalam memeriksa dan memutus perkara, telah memberi peluang besar bagi hakim dalam mewujudkan keadilan yang berdasar kepada Ketuhanan Yang Maha Esa, karena bagaimanapun juga hukum hanyalah sarana, sedangkan keadilan adalah tujuan akhir, sehingga hakim harus memiliki keberanian menafsirkan, mengkonstruksi ataupun

\footnotetext{
${ }^{25}$ Ibid

${ }^{26}$ Ibid.

${ }^{27}$ Ibid.
} 
melenturkan aturan hukum, bahkan mengesampingkan demi tujuan yang akan dicapai dalam pemeriksaan perkara, yaitu keadilan berdasarkan Ketuhanan Yang Maha Esa.Pemerintah melalui undang-undang telah memberikan titik tolak peradilan, yaitu dilakukan demi keadilan berdasarkan Ketuhanan Yang Maha Esa.

Dasar peradilan ini, merupakan syarat bathiniah bagi hakim dalam melaksanakan keadilan yang merupakan pertanggungjawaban kepada Tuhan Yang Maha Esa, dan hal ini merupakan dasar filosofis dari putusan hakim, yakni rasa adil yang diberikan oleh pencipta rasa keadilan, yaitu Tuhan Yang Maha Esa, sehingga putusan akan memberikan rasa tenteram dan damai bagi para pihak yang berperkara.Hakim disamping sebagai mahkluk Tuhan, juga sebagai mahkluk mandiri, dan karena itu, ia mempunyai kemerdekaan berpikir, namun semua yang diperbuatnya harus dapat dipertanggung-jawabkan kepada Tuhan Yang Maha Esa.

Dari hasil penelitian terhadap putusan hakim pada perkara tindak pidana, diperoleh informasi mengenai nilai-nilai yang tercermin dalam putusan hakim, sebagaimana pada tabel berikut ini.

Tabel 1

Pendapat Responden Tentang Nilai Keadilan Pada Putusan Hakim Dalam Perkara Tindak Pidana Korupsi

\begin{tabular}{|c|c|c|c|}
\hline No & Kategori & Jumlah (F) & Prosentase (\%) \\
\hline 1. & Sudah mencerminkan & 19 & 95 \\
2. & Kurang mencerminkan & 1 & 5 \\
3. & Tidak mencerminkan & - & - \\
\hline \multicolumn{2}{|r}{} & 20 & 100,00 \\
\hline
\end{tabular}

Sumber: Data Primer setelah diolah, 2017.

Berdasarkan data pada tabel 1 di atas, tampak bahwa dari 20 responden terdapat 19 (95\%) responden yang berpendapat bahwa putusan hakim dalam perkara tindak pidana korupsi sudah mencerminkan nilai-nilai keadilan. Kendatipun terdapat 1 responden, yang justru memandang kurang mencerminkan nilai keadilan.Realitas ini, memberi indikasi bahwa dalam pelaksanaan peradilan terhadap tindak pidana korupsi, hakim telah menjalankan tugas dan tanggung jawabnya dengan baik, yaitu menegakkan hukum dan keadilan.Selain itu, hakim dalam memutuskan perkara tindak pidana korupsi, telah mewujudkan nilai keadilan sesuai standar aturan hukum, atau indikator-indikator yang telah ditentukan dalam ketentuan.Hal ini, dapat diketahui dari hasil penelitian sebagaimana dapat dilihat pada tabel berikut ini. 
Tabel 2

Pendapat Responden Tentang Indikator

Putusan Hakim Yang Mangandung Nilai Keadilan.

\begin{tabular}{|c|l|c|c|}
\hline No & \multicolumn{1}{|c|}{ Kategori } & Jumlah (F) & Prosentase (\%) \\
\hline 1. & Mempertimbangkan alat bukti & 6 & 30 \\
2. & Menerapkan ketentuan & 12 & 60 \\
& sebagaimana mestinya & 2 & 10 \\
\hline 3. & Memuat alasan-alasan hukum & 20 & 100,00 \\
\hline
\end{tabular}

Sumber: Data Primer setelah diolah, 2017.

Dari tabel 2 di atas, menunjukkan bahwa indikator utama yang dijadikan dasar adanya putusan hakim yang mengandung nilai keadilan, adalah diterapkannya ketentuan atas kasus tindak pidana korupsi sebagaimana mestinya. Hal ini, tampak dari persepsi responden yang pada umumnya, yaitu sebanyak 12 (60\%) responden menilai putusan yang mengandung nilai keadilan pada penerapan aturan yang sesuai dengan ketentuan tindak pidana korupsi. Sedangkan responden lainnya, yaitu $6(30 \%)$ responden lebih fokus pada putusan hakim dianggap adil jika sudah mempertimbangkan alat bukti, dan $2(10 \%)$ responden memandang putusan hakim sudah mengandung nilai, jika memuat dan berpijak pada alasan-alasan hukum yang mendasari putusan hakim. Dengan demikian, penilaian atas perwujudan nilai-nilai keadilan putusan hakim dalam perkara tindak pidana korupsi masih sangat variatif, sebagai akibat tidak adanya kesepakatan secara umum mengenai indikator penilaian atas putusan hakim yang mengandung nilai-nilai keadilan.Dalam realitasnya, yang penting sudah sesuai dengan ketentuan, maka hal tersebut sudah dianggap adil (keadilan prosedural).Meskipun oleh pandangan masyarakat putusan hakim tersebut, justru dipandang tidak mengandung nilai keadilan atau mungkin bahkan dianggap putusan hakim tersebut sangat tidak adil (keadilan substansial).

\section{B. Kriteria Putusan Hakim Pada Perkara Pidana Korupsi Yang Mencerminkan Nilai Keadilan}

Memutus suatu perkara berarti menegakkan keadilan atas suatu perkara tindak pidana korupsi, atau dengan kata lain menegakkan hukum pidana materil. Untuk penegakan hukum pidana materil diperlukan suatu proses berdasarkan ketentuan perundang-undangan. Konsep keadilan atau kesamaan merupakan hal yang sangat penting dalam setiap peradilan. Sebagai suatu peradilan yang menjalankan kekuasaan kehakiman, hakim harus dapat memberi keadilan kepada para pencari keadilan, maka putusan hakim juga diartikan sebagai keadilan yang diberikan oleh hakim kepada pencari keadilan setelah 
melalui proses beracara dalam persidangan.Dalam hukum acara pidana ditemukan prinsip-prinsip peradilan yang harus dipahami dan diterapkan, baik secara formal maupun substantif guna mewujudkan putusan yang adil.Untuk mencapai putusan yang adil hanya dapat diwujudkan, jika hukum acara pidana terlaksana baik formal maupun substansinya dalam pemeriksaan kasus tindak pidana korupsi. Dengan demikian, dapat dihindari terjadinya putusan hakim yang mengandung ketidakadilan.

Secara umum, semua peradilan negara harus menerapkan konsep keadilan sebagaimana ditetapkan pada Pasal 5 ayat (1) Undang-Undang No. 48 Tahun 2009 tentang Kekuasaan Kehakiman (selanjutnya disebut UUKK). Konsep keadilan yang dianut dalam tiap-tiap peradilan berbeda berbeda satu sama lain. Dalam hukum cara pidana, konsep keadilan mengingatkan agar setiap pelaku tindak pidana korupsi mendapat perlakuan yang adil, seperti diberi kesempatan untuk mengajukan pembelaan diri, dan bahkan terdakwa mempunyai kesempatan untuk membuktikan bahwa dia tidak melakukan perbuatan seperti yang didakwakan kepadanya.Seorang hakim yang telah memutuskan suatu perkara dengan adil, belum tentu adil menurut orang lain. Begitu juga dengan kebenaran menurutnya belum tentu benar menurut orang lain. Keadilan dan kebenaran yang dijadikan dasar hukum belum tentu sesuai dengan keadilan dan kebenaran menurut masyarakat.

Dalam aliran deontologikalisme yang terpenting, adalah komitmen cara atau mekanisme untuk mewujudkan keadilan. ${ }^{28}$ Yang oleh para pengikutnya sering diungkapkan dengan menyatakan bahwa "tegakkanlah hukum untuk mencapai keadilan meskipun langit akan runtuh ", atau dalam ungkapan lain yang menekankan pada mekanisme, atau prosedur yang menyatakan "apapun yang terjadi janganlah berkata bohong ".Ungkapan tersebut, menunjuk pada pentingnya proses atau cara mewujudkan keadilan, melalui penegakan hukum dan kejujuran. Cara atau prosedur dinyatakan adil, jika dalam prosedur memenuhi unsur kelayakan, kebebasan dan kesamaan. Keadilan yang lebih menekankan pada cara atau mekanisme mewujudkan keadilan dalam konteks putusan hakim di pengadilan perlu mendapat perhatian, karena keadilan menurut pandangan deontologikalisme ini, banyak menuai kritik disebabkan karena kadang-kadang ada perlakuan tidak adil yang dialami oleh para pihak, ataukah terdakwa dalam kasus tindak pidana korupsi.

Mewujudkan keadilan menurut pandangan deontologikalisme tidak saja dalam proses peradilan yang penekannnya pada cara, prosedur, mekanisme (hukum acara), tetapi harus juga sampai pada putusan akhir. Mewujudkan keadilan dengan memadukan antara cara atau mekanisme dan hasil akhir putusan pengadilan tidak semudah yang dibayangkan. Menurut Maria SW. Soemaryono bahwa “tidak mudah

${ }^{28}$ Nur Hasan Ismail, Disertasi, Perkembangan Hukum Pertanahan Indonesia; Suatu Pendekatan Ekonomi Politik, (Yogjakarta: Fakultas Hukum Universitas Gajah Mada, 2006), hal. 45-46. 
menentukan pilihan antara memutuskan sesuatu yang secara formal memenuhi syarat, namun tidak memenuhi syarat keadilan secara substansial, atau mengutamakan terpenuhinya keadilan secara substansial, namun secara formal tidak memenuhi syarat. Kemungkinan yang dapat dijadikan pedoman adalah suara hati nurani disertai empati, karena justru pada saat terjadi sesuatu yang dirasakan kurang adil orang, akan berfikir mengenai apa yang disebut dengan keadilan itu. Demikian halnya keadilan tidak selalu dapat diperoleh dengan mudah, namun harus terus menerus diupayakan agar dapat terwujud..$^{29}$

Putusan Hakim diharapkan sedapat mungkin harus memenuhi rasa keadilan, yaitu keadilan yang dirasakan oleh para pihak dalam berperkara. Keadilan yang dimaksud sedapat mungkin keadilan substansial, bukan keadilan formal, maknanya adalah sebagai suatu keadilan yang riil diterima dan dirasakan oleh para pihak berperkara. Sementara keadilan formal dimaknai sebagai keadilan yang berdasarkan atas hukum semata, yang belum tentu dapat diterima dan dirasakan adil oleh para pihak.

Karena itu, indikator yang mencerminkan nilai kepadilan pada putusan hakim, dapat diukur dengan meninjau profesionalisme dan integritas moral hakim dalam penanganan kasus tindak pidana korupsi.

\section{Profesionalisme Hakim}

Profesionalisme diartikan sebagai mutu, kualitas dan tindak tanduk berlandaskan etika yang merupakan suatu ciri suatu profesi atau orang yang professional.Dalam hubungannya dengan profesi hakim berarti bagaimana mutu dan kualitas hakim sebagai penegak keadilan, baik dalam tingkah laku dan tindakannya serta mutu dan kualitas putusannya (produk hakim sebagai penegak keadilan).Tentang bagaimana profesionalisme hakim dalam menegakkan keadilan dalam putusannya, dan bagaimana nilai-nilai keadilan putusan tersebut, dapat ditemukan pada putusan hakim itu sendiri.

Hakim sebagai penegak hukum selalu dituntut untuk profesional.Profesionalisme hakim akan terwujud bila mana hakim memiliki ciri-ciri profesionalisme, ada empat ciri-ciri yang bisa ditengarai sebagai petunjuk atau indikator untuk melihat tingkat profesionalitas seseorang, ${ }^{30}$ yaitu:

1. Penguasaan ilmu pengetahuan seseorang dibidang tertentu, dan ketekunan mengikuti perkembangan ilmu yang dikuasai;

2. Kemampuan seseorang dalam menerapkan ilmu yang dikuasai, khususnya yang berguna bagi kepentingan sesama;

29 Maria SW. Soemarjono, Pedoman Pembuatan Usulan Penelitian Sebuah Panduan Dasar, (Jakarta: Gramedia Pustaka Utama, 2006), hal. 176.

${ }^{30}$ Asep Ridwan, "Profesionalime Sebagai Landasan Kualitas Hakim Agama" http://www.pakalianda.go.id/gallery/artikel/199-profesionalime-sebagai-landasan-kualitas-hakim-agama.html diakses pada 12 Oktober 2012. 
3. Ketaatan dalam melaksanakan dan menjunjung tinggi etika keilmuan, serta kemampuannya untuk memahami dan menghormati nilai-nilai sosial yang berlaku dilingkungannya;

4. Besarnya rasa tanggungjawab terhadap Tuhan, bangsa dan negara, masyarakat, keluarga, serta diri sendiri atas segala tindak lanjut dan perilaku dalam mengemban tugas berkaitan dengan penugasan dan penerapan bidang ilmu yang dimiliki.

\section{Integritas Moral Hakim}

Moralitas adalah kualitas perbuatan manusia, sehingga perbuatan itu disebut benar atau salah, baik atau buruk, dimana jika moralitas rendah membuat mutu manusia menjadi rendah, demikian pula sebaliknya.

Dalam konteks penegakan hukum, derivasi dari penggolongan hakim di atas, dapat dikategorikan ke dalam tiga macam, yaitu: hakim yang idealis, hakim yang materialis dan hakim yang idealis-materialis.

Ukuran kualitas putusan hakim adalah peran hakim untuk mewujudkan keadilan, kemanfaatan dan kepastian hukum bagi pencari keadilan, sehingga penolakan terhadap putusan hakim melalui upaya hukum banding atau upaya hukum kasasi, maupun upaya hukum peninjauan kembali (PK) telah mencerminkan kepuasan dan/atau ketidakpuasan pencari keadilan, terhadap peran hakim dalam mewujudkan tujuan hukum tersebut.

Berdasarkan hasil penelitian menunjukkan bahwa banyakputusan hakim yang oleh pihak yang terlibat kasus korupsi melakukan penolakan terhadap putusan pengadilan, sehingga dilakukan upaya hukum banding.Dalam hubungan moralitas dengan fungsi hakim dalam menegakkan keadilan, maka yang harus diperhatikan ialah sasaran pemeriksaan perkara yang diinginkan oleh hakim untuk mencapai sasaran serta hal-hal yang mempengaruhi tindakan dan perbuatan hakim.Secara formal dan substantif sasaran pemeriksaan perkara, adalah putusan adil. Sedangkan yang diinginkan oleh hakim guna mencapai sasaran, ialah memeriksa perkara berdasarkan kaidah-kaidah hukum yang mengandung nilai keadilan.

Tabel 3

Pendapat Responden Tentang Integritas Hakim

Dalam Menjatuhkan Putusan

\begin{tabular}{|c|c|c|c|}
\hline No & Kategori & Jumlah (F) & Prosentase (\%) \\
\hline 1. & Memiliki integritas & 18 & 90 \\
2. & Kurang memiliki integritas & 2 & 10 \\
3. & Tidak memiliki integritas & - & - \\
\hline & Jumlah & 20 & 100,00 \\
\hline
\end{tabular}

Sumber: Data Primer setelah diolah, 2017. 


\section{Faktor-FaktorYang Mempengaruhi Putusan Hakim Sehingga Tidak Mencerminkan Nilai Keadilan.}

\section{Kualitas Hakim}

Dalam menentukan kualitas hakim dapat dilihat dari aspek pendidikan formal (ilmu) dan pemahamannya terhadap kaidah hukum materil dan hukum formal (hukum acara pidana) serta pemahamannya terhadap keadilan itu sendiri.

Dari hasil penelitian, menunjukkan bahwa kalangan hakim belum seluruhnya berpendidikan Magister Hukum (S2), masih terdapat hakim yang berpendidikan Sarjana Hukum (S1).Realitas ini, memberi indikasi bahwa secara formal kualitas hakim sebagai penegak hukum dan keadilan masih sangat rendah.Demikian pula dengan pemahaman hakim terhadap hukum dan keadilan yang masih sangat sempit, dan tidak komprehensif atas pelaksanaan prinsip-prinsip peradilan yang adil, menjadi isyarat rendahnya kualitas ilmu yang dimiliki hakim, sehingga menyebabkan banyak putusan yang dianggap tidak memberikan keadilan atau tidak mengandung nilai-nilai keadilan.Karena itu, menurut Muhammad Damis selaku Ketua Pengadilan Negeri Sungguminasa (Wawancara) bahwa agar putusan hakim mengandung nilai-nilai keadilan pada perkara tindak pidana korupsi, maka diperlukan peningkatan kapasitas hakim tindak pidana korupsi dan legal culture.

Pendidikan yang tinggi akan memberikan parameter kinerja yang tinggi dan terukur. Standar kinerja hakim yang ideal seharusnya berorientasi pada peningkatan integritas dan profesionalisme hakim, bukan untuk melemahkan independensi hakim. Karena itu, faktor pendidikan adalah salah satu hal yang sangat mendukung, sehingga semakin tinggi pendidikan seseorang, maka semakin tinggi pula daya nalar dan analisis terhadap suatu persoalan. Kompleksitas persoalan yang berada dalam ranah penegakan hukum, khususnya berkaitan dengan dunia peradilan adalahsangat memerlukan daya nalar dan analisis yang tinggi, sistematis, dan komprehensif.

\section{Kemandirian Hakim}

Kemandirian kekuasaan kehakiman mempunyai implikasi terhadap penegakan hukum oleh hakim di muka persidangan, karena sikap hakim akan menentukan obyektivitasnya dalam memutuskan perkara. Hal ini menunjukkan bahwa hakim mempunyai kedudukan istimewa, karena menjadi benteng terakhir bagi para pencari keadilan. Selain itu, hakim juga merupakan Ultimum Remedium, yang menjadi senjata pamungkas bagi semua kekisruhan dalam penegakan hukum. Untuk itu, lembaga peradilan dalam menyelenggarakan fungsinya haruslah diberikan kemandirian tanpa adanya tekanan, karena jika tidak ada kebebasan dan kemandiriannya, maka masyarakat tentunya tidak dapat berharap banyak kepada para hakim untuk dapat memperoleh putusan yang adil, dan mungkin malah sebaliknya putusan hakim menjadi tidak obyektif, serta terjadi keberpihakan pada salah satu pihak yang berperkara. Kendatipun ada jaminan kemandirian hakim dalam proses penyelenggaraan kekuasaan kehakiman secara konstitusional, namun 
tampaknya belum sepenuhnya dapat diwujudkan, karena adanya berbagai faktor yang mempengaruhinya.

Kemandirian hakim dalam menyelenggarakan proses peradilan telah ditegaskan dalam Pasal 3 ayat (1) Undang Undang Nomor 48 Tahun 2009 bahwa dalam menjalankan tugas dan fungsinya, hakim dan hakim konstitusi wajib menjaga kemandirian peradilan. Kewajiban bagi hakim untuk menjaga kemandiriannya dalam proses peradilan, mengandung arti bahwa pada dasarnya hakim tidak boleh terpengaruh oleh campur tangan dari pihak manapun dalam menjalankan tugas dan fungsinya. Karena itu, hakim wajib menjaga kemandiriannya dengan tetap bersikap objektif dalam memeriksa dan memutus perkara.

\section{Intervensi}

Hakim sebagai benteng terakhir dalam penegakan hukum di lembaga pengadilan mempunyai peranan penting untuk mewujudkan rasa keadilan ditengah masyarakat. Dalam pengambilan keputusan, maka setiap hakim (Ketua Majelis) diwajibkan untuk memberitahukan akan hak-hak para pihak atau terdakwa terhadap putusan yang dijatuhkan oleh hakim tersebut, untuk menerima atau menolak dengan menyatakan banding ke Pengadilan Tinggi. Jika tidak maka hakim akan dianggap lalai dan hal tersebut dapat merugikan pihak-pihak yang berperkara. Dengan demikian, penegakan hukum terhadap hakim dalam pengambilan suatu kebijaksanaan hukum mutlak diperlukan, baik penegakan hukum administrasi maupun penegakan hukum pidana terhadap para hakim yang melanggar standar norma hukum yang telah ditetapkan.

Tidak dapat disangkali bahwa selama ini lembaga pengadilan memiliki banyak kelemahan yang secara terus-menerus perlu diperbaiki, terutama integritas, kualitas, mentalitas dan kinerja hakim.Fakta ini, yang menyebabkan keadilan tidak dapat dirasakan oleh pencari keadilan.Dalam prakteknya publik masih mendengar putusan-putusan kontroversial yang dibuat oleh hakim, padahal dalam mengemban fungsinya, hakim seharusnya membuat keputusan-keputusan yang adil dan bijaksana dengan mempertimbangkan implikasi hukum dan dampaknya yang terjadi pada masyarakat.

Meningkatnya perkara-perkara yang melibatkan para pejabat baik legislatif, eksekutif, dan yudikatif menambah tugas berat bagi pengadilan utamanya para hakim dalam menyelenggarakan proses persidangan. Demikian pula meningkatnya frekuensi unjuk rasa akhir-akhir ini, karena pelaksanaan putusan pengadilan (eksekusi), dan kecurigaan terhadap tidak ada keadilan terhadap putusan tertentu, kecurigaan terhadap hakim yang mengadili.

Situasi demikian menjadikan ada kekhawatiran bagi hakim dalam menjalankan tugasnya, yang pada akhirnya tidak mustahil akan muncul pemeo dari pada repotrepot hukum saja, yang justru akan sangat membahayakan kondisi penegakan hukum untuk masa-masa yang akan datang. Pada hal seseorang diajukan kesidang 
pengadilan adalah untuk diadili, untuk dibuktikan kesalahannya, bukan untuk dihukum. Kalau hanya untuk dihukum akan lebih baik kalau tidak diajukan ke pengadilan. Hal ini, tampak dari hasil penelitian, dimana penyebab putusan hakim dalam perkara tindak pidana korupsi sudah tidak mencerminkan nilai keadilan, sebagaimana terlihat pada tabel berikut ini.

\section{Tabel 4}

\section{Pendapat Responden Tentang Adanya Intervensi Dalam Menjatuhkan Putusan}

\begin{tabular}{|c|l|c|c|}
\hline No & \multicolumn{1}{|c|}{ Kategori } & Jumlah (F) & Prosentase (\%) \\
\hline 1. & $\begin{array}{l}\text { Pengaruh tuntutan masyarakat } \\
\text { Menghukum koruptor agar tidak } \\
\text { dicurigai }\end{array}$ & 18 & 90 \\
3. & Hakim tidak mau menanggung resiko & 2 & - \\
\hline \multicolumn{2}{|c|}{ Jumlah } & 20 & 10 \\
\hline
\end{tabular}

Sumber: Data Primer setelah diolah, 2017.

Berdasarkan data pada tabel 4 di atas, tampak bahwa hakim dalam menjatuhkan putusan tidak lagi berdasarkan hukum dan keadilan, melainkan dominan lebih dipengaruhi oleh pengaruh tuntutan masyarakat. Hal ini, tampak dari 20 responden terdapat 18 responden (90\%) memandang putusan hakim lebih banyak dipengaruhi oleh tuntutan masayarakat. Konsekuensinya dapat dipastikan bahwa putusan hakim sudah pasti tidak akan mencerminkan nilai-nilai keadilan. Selain itu, hakim dalam mengambil putusan tidak mau menanggung resiko, sebagaimana 2 responden $(10 \%)$ memberi penilaian atas putusan hakim selama ini. Pendapat responden tentang adanya intervensi dalam menjatuhkan putusan.

\section{Penutup}

Nilai keadilan putusan hakim pada perkara tindak pidana korupsi pada hakikatnya untuk mencegah terjadinya perlakuan yang tidak seimbang atau memihak, namun secara faktual kurang diwujudkan sehingga putusan hakim dirasakan oleh pencari keadilan sebagai putusan yang tidak mengandung nilai-nilai keadilan, tetapi semata-mata hanya bertendensi penghukuman dan melanggar hak dari pelaku tindak pidana.Putusan hakim pada perkara pidana korupsi yang mencerminkan nilai keadilan ditentukan dengan kriteria, jika putusan hakim dilakukan dengan secara professional, dan didukung dengan integritas moral hakim yang tinggi, maka putusan hakim sudah dipandang mengandung nilai-nilai keadilan.Faktor-faktor yang mempengaruhi putusan hakim, sehingga kurang mencerminkan nilai keadilan pada perkara tindak pidana korupsi disebabkan karena kualitas hakim, kemandirian hakim dan adanya intervensi dalam memeriksa dan mengadili perkara.Untuk mewujudkan adanya nilai keadilan dalam putusan perkara 
pidana diperlukan adanya independensi dan akuntabilitas hakim Pengadilan Tipikor dalam memeriksa dan mengadili perkara tindak pidana korupsi.

\section{Daftar Pustaka}

Andi Hamzah, 2012. Hukum Acara Pidana Indonesia, Sinar Grafika, Jakarta.

Edi Yunara, 2012. Korupsi dan Pertanggungjawaban Pidana Korporasi, PT. Citra Aditya Bakti, Bandung.

Maria SW. Soemarjono, 2006, Pedoman Pembuatan Usulan Penelitian Sebuah Panduan Dasar, Gramedia Pustaka Utama, Jakarta.

Muchsin, 2004, Kekuasaan Kehakiman Yang Merdeka E Kebijakan Asasi, STIH IBLAM, Depok.

Muhammad Ali, 2009. Kamus Lengkap Indonesia Modern, Penerbit Pustaka Amani, Jakarta.

Paulus Hadi Suprapto, 2009, Menemukan Substansi Dalam Keadilan Prosedural, Komisi Yudisial, Jakarta.

Sudikno Mertokusumo, 1991. Mengenal Hukum, Liberty, Yogyakarta.

Sukarno Aburaera \& Muhadar \& Maskun, 2013. Filsafat Hukum, Kencana Prenada Media Group, Jakarta.

Wahju Muljono, 2012. Pengantar Teori Kriminologi, Pustaka Yustisia, Yogyakarta.

Peraturan Perundang - Undangan:

Undang-Undang Dasar NRI Tahun 1945

Undang-undang Nomor 31 Tahun 1999 Tentang Tindak Pidana Korupsi

Undang-undang Nomor 48 Tahun 2009 Tentang Kekuasaan Kehakiman. 